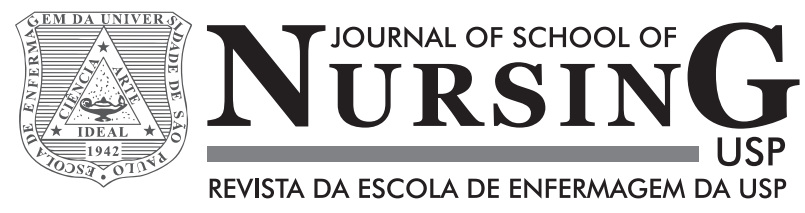

\title{
Nursing beliefs and actions in exercising patient advocacy in a hospital context*
}

\author{
Crenças e ações de enfermeiros no exercício da advocacia do paciente no contexto hospitalar \\ Creencias y acciones de enfermeros en el ejercicio de la \\ defensa del paciente en el marco hospitalario
}

Jamila Geri Tomaschewski Barlem¹, Valéria Lerch Lunardi¹, Edison Luiz Devos Barlem, Aline Marcelino Ramos², Aline Belletti Figueira ${ }^{2}$, Nerizane Cerutti Fornari ${ }^{1}$

\footnotetext{
* Extracted from the thesis "O exercício da advocacia do paciente pelos enfermeiros: uma perspectiva foucaultiana”, Programa de PósGraduação em Enfermagem, Universidade Federal do Rio Grande, 2014.

${ }^{1}$ Universidade Federal do Rio Grande, Escola de Enfermagem, Rio Grande, RS, Brazil.

${ }^{2}$ Universidade Federal do Rio Grande, Programa de Pós-Graduação em Enfermagem, Rio Grande, RS, Brazil.
}

\section{ABSTRACT}

Objective: Analyzing beliefs and actions of nurses in exercising patient advocacy in a hospital context. Method: A quantitative cross-sectional exploratory and descriptive study, conducted with 153 nurses from two hospitals in southern Brazil, one public and one philanthropic, by applying Protective Nursing Advocacy Scale - Brazilian version. Data were analyzed using descriptive statistics and analysis of variance. Results: Nurses believe they are advocating for patients in their workplaces, and agree that they should advocate, especially when vulnerable patients need their protection. Personal values and professional skills have been identified as major sources of support for the practice of advocacy. Conclusion: Nurses do not disagree nor agree that advocating for patients in their working environments can bring them negative consequences. It is necessary to recognize how the characteristics of public and private institutions have helped or not helped in exercising patient advocacy by nurses.

\section{DESCRIPTORS}

Patient Advocacy; Patient Rights; Nurse-Patient Relations; Ethics, Nursing; Nurse's Role. 


\section{INTRODUCTION}

In the Brazilian context, investigations on moral distress have highlighted situations where we identified inconsistency between our actions, beliefs and knowledge ${ }^{(1)}$ and which seem fairly common in the everyday work life of many health institution nursing workers ${ }^{(2-6)}$. Similarly, situations that commonly give rise to moral suffering refer back to the need for exercising nursing autonomy and patient advocacy as part of their work ${ }^{(2)}$.

Patient advocacy exerted by nurses aims to help the patient obtain necessary health care, defend their rights, ensure quality of care and serve as a connection between patients and the health care environment. It is mainly associated by nurses recognizing their role as health advocates, considering their beliefs and actions in relation to the care they provide to patients ${ }^{(7-9)}$.

Although patients are not always regarded as vulnerable, the combination of hospitalization, illness and subjection to care by the health team can be a difficult situation in which to fully express their opinions and choices. Still, as the use of advanced technology and healthcare costs have ignored the autonomy and values of patients, patient advocacy has been consolidated as a purpose of nurses to engage in the resolution of healthcare system problems and possible disparities which arise ${ }^{(10)}$.

By assuming the moral commitment to exercise patient advocacy, nurses can demonstrate that they are in a unique position in healthcare relations and may help patients to clarify the objectives of their treatment, in making health related decisions, and coping with many challenges posed by traditional health structures and their power relations ${ }^{(7,10-11)}$. Thus, patient advocacy can be considered a response to the constant moral problems experienced by patients in health care settings, especially the possibility of confrontation in their work environments, culminating in potential benefits to patients and to the profession ${ }^{(5)}$.

Assuming the patient's advocate role can be directly related to the exercise of parrbesia by nurses, the courage of truth, of disruption and of complaint, the courage to reveal truths by its action that are commonly implied in daily nursing work, but which are not questioned or even modified $^{(12)}$. Thus, the exercise of parrhesia as a manifestation of the exercise of power can contribute to nurses advocating for patients in their work environments, allowing them to experience new opportunities for action and realize their own truth ${ }^{(13)}$.

However, nurses can feel immersed in states of domination on a daily basis, given that in many situations of professional practice their ability to exercise resistance or to counteract those who wield power is not present. This can bring them great suffering, because even in believing that they should implement certain morally right actions, they choose to give up fighting due to the imposition of external forces. Thus, it is possible to notice that often nurses do not seem to realize sufficient confrontations in their work environments, living in an apparent normality with situations that cause them stress, burnout and moral suffering ${ }^{(3,6)}$, which consequently may compromise exercising patient advocacy.
Power relations have a productive dimension in human relationships because there is a whole set of actions and reactions that can be exercised between individuals ${ }^{(14)}$. In this sense, patient advocacy in nursing seems to have a close relationship with the exercise of power, and may be seen as a motivational construct to nursing itself, since it can create opportunities to confront the physical and social needs of healthcare environments ${ }^{(15-16)}$, revealing forms of ethical resistance.

While in the international scenario, the issue of patient advocacy is already being widely investigated, but in the Brazilian context there are no studies about nurses' beliefs and actions in exercising patient advocacy, which justifies this study. Identifying the beliefs and actions of nurses in exercising patient advocacy in the Brazilian context can contribute to understanding how nurses are carrying out confrontations to act in the best interests of patients, thereby demonstrating the relevance of this study.

Given the above, the question arises: What are the beliefs and actions of nurses in exercising patient advocacy in a hospital context? With the aim being to analyze nurses' beliefs and actions in exercising patient advocacy in a hospital context.

\section{METHOD}

A quantitative exploratory-descriptive study with crosssectional design conducted in two hospitals in southern Brazil, one public and one philanthropic. The first institution, referred to as "H1," is characterized as a university hospital that caters exclusively to users of the Unified Healthcare System (SUS). It has 195 beds and has 67 nurses, mostly public contested civil servants, and a lesser quantity governed by the Consolidation of Labor Laws (CLT), both working 30 hours weekly. The second institution, referred to as "H2," is characterized as a philanthropic organization, serving the SUS, private and health insurance patients, and is constituted by three different hospitals: the General hospital, Cardiology hospital and Oncology and Psychiatric hospital, comprising a total of 644 beds. It has a staff of 174 nurses, governed by the Labor Laws, with a workload of 36 to 40 weekly hours, according to their location.

The study was carried out with a sample of 153 nurses, adopting the following inclusion criteria: being a nurse, acting professionally in the respective hospitals, having availability and interest to respond to the data collection instrument. For subject selection, a non-probability sampling for convenience was used, where all nurses working in these hospitals that were in their workplaces during the data collection period were invited to participate in the research. The sample size was defined by specific mathematical formula ${ }^{(17)}$, which aims to estimate the minimum sample size to make it possible to carry out certain statistical procedures, ensuring study reliability. By previously knowing the total population composed of 241 nurses and applying the formula ${ }^{(17)}$, the minimum number of 150 informants was found.

For data collection, we used the Protective Nursing Advocacy Scale Instrument - Brazilian version, culturally adapted 
and validated by the authors of this research ${ }^{(18)}$ from the original Protective Nursing Advocacy Scale ${ }^{(8)}$ instrument. The original instrument ${ }^{(8)}$ consists of 43 questions that can be answered through a Likert scale of five points, using 1 for I strongly disagree, 2 for I disagree more than I agree; 3 for I neither agree nor disagree, 4 for I agree more than I disagree and 5 for I strongly agree.

The instrument was culturally adapted to the Brazilian context according to international recommendations through an initial translation, synthesis of translations, back translation, an expert committee, pretest and revision of the adaptation process by the researchers, which allowed for considering the validity of the face and content of the instrument as satisfactory. The construct validation of the instrument for use in the Brazilian context was conducted by factor analysis and Cronbach's alpha. Of the 43 questions posed by the instrument by factor analysis, 20 were validated for this study in five constructs: negative implications of patient advocacy; advocacy actions; facilitating advocacy practice; perceptions that favor advocacy practice; barriers to practicing patient advocacy. The instrument presented a Cronbach's alpha value of 0.78 , while the coefficients of the five constructs were between 0.70 and 0.87 , values considered high for exploratory studies.

The applied instrument also had an initial part of subject characterization, containing sociodemographic characteristics that could be significant for correlation with patient advocacy, such as: age, gender, training time, work institution, working hours, professional performance time, other completed courses (specialization, master's, doctorate), type of service (SUS or mixed, involving SUS, health insurance and private patients) and meetings in the work unit ${ }^{(8)}$.

Data collection was carried out between the months of January and February 2014, by four previously trained undergraduate researchers. By visiting the units of the two selected hospitals, the instruments were delivered directly to informants in a manila envelope, without identification, together with the Clear and Informed Consent Form. After the distribution of instruments and consent forms, the return scheduling was carried out by setting up a maximum of three attempts at different locations for the collection of previously delivered instruments.

The results of the study sample were obtained through descriptive statistics, using medium and frequency distribution of the constructs and its indicators; and analysis of variance (ANOVA) between different groups of respondents according to sample characteristics in order to verify possible significant differences. Data were submitted to normality test, checking for normal distribution. Data analysis was performed using the SPSS statistical software (Statistical Package for Social Sciences) version 22.0, facilitating the process of organizing data in tables that allowed for better visualization of the results and their interpretation.

Ethical aspects were respected according to the recommendations of the National Health Council Resolution $466 / 12$, so that the study was approved by the Ethics in Local Research Committee (Number 97/2013).

\section{RESULTS}

Regarding the studied sample's characteristics, it was found that the 153 nurses had an average of 33 years of age (33.13\%), and most were females (89.5\%). Of the 153 nurses, 51 (33.3\%) worked in the "H1" hospital and 102 (66.7\%) in the "H2" hospital. The average training time was seven years (7.04), ranging from three months to 44 years since graduation. Professional experience time ranged between one month and 43 years, and six years (6.49) was the average of professional activity time. When asked about meetings in the work unit, $76.3 \%$ of subjects said they had meetings.

With regard to the results of the evaluation of nurses beliefs and actions regarding patient advocacy, descriptive analysis (Table 1) allowed to verify that the construct perceptions that favor the practice of advocacy had the highest average of the instrument (4.33), noting that nurses agree that they should advocate for patients, especially when they are vulnerable and are needing protection in harmful situations (4.44). Similarly, nurses agree that understanding the benefits of advocacy (4.40), providing information to patients about their care (4.23) and recognizing that patients have varying degrees of ability to defend themselves (4.24) favors the exercise of advocacy in health.

In the advocacy actions construct, the corresponding average was equal to 3.99 , indicating that nurses agree that they are advocating for patients in their work environments. In this construct, the question Am I acting on behalf of the patient when I'm acting as his advocate had the highest average (4.18).

The construct facilitators for the practice of advocacy had an average of 4.26 , showing that nurses agree that personal values and professional skills are the main sources of support for health advocacy actions. The question nurses who are committed to providing good patient care are the best patient advocates had the highest average in this construct (4.42).

The construct barriers for the practice of advocacy had the lowest average of the instrument (1.86), noting that nurses disagree that barriers such as burnout and moral suffering and lack of dedication to nursing may prevent them from fully realizing their role as patient advocates. Regarding negative implications of the practice of advocacy, nurses showed that they do not disagree nor agree (3.00) that advocating for patients in their workplaces can have negative consequences for them.

ANOVA (Table 2) allowed for analyzing the existence of possible differences in the average of the constructs of the beliefs and actions of nurses in exercising patient advocacy, considering their socio-demographic characteristics. There were significant differences for the duration of training and time of professional experience for both in the negative implications of practicing advocacy construct. Nursing graduates with less time and with less experience showed greater disagreement regarding the negative implications of practicing advocacy.

Furthermore, a significant difference was identified between the service type variable and the construct barriers to practicing advocacy, noting that nurses serving exclusively to SUS patients have greater disagreement regarding the barriers to practicing advocacy when compared to nurses 
who attend patients of mixed units (SUS/health insurance and private patients). It is noteworthy to mention that there were no significant differences with respect to the beliefs and actions of nurses according to the hospitals studied, even when dealing with the different organizations, being public and philanthropic.

Table 1 - Average of the beliefs and actions of nurses in exercising patient advocacy - Rio Grande, RS, Brazil, 2014.

\begin{tabular}{|c|c|c|}
\hline Factors & $\mathbf{n}$ & Average \\
\hline Negative implications of the practice of advocacy & 151 & (3.00) \\
\hline q30 It can be risky for my job to act as a patient advocate & 149 & 2.93 \\
\hline q31 Nurses who speak for the patients may suffer retaliation from their employers & 150 & 3.37 \\
\hline q32 I could be punished for my actions by my employer when I inform patients about their rights & 149 & 2.81 \\
\hline q33 Nurses who speak on behalf of vulnerable patients may be labeled as troublemakers by employers & 151 & 3.17 \\
\hline q34 When nurses inform and teach patients about their rights in the clinical setting, they may be putting their jobs at risk & 151 & 2.74 \\
\hline Advocacy actions & 153 & (3.99) \\
\hline q5 I am acting on behalf of the patient when I'm acting as their advocate & 153 & 4.18 \\
\hline q6 I am speaking on behalf of the patient when I'm acting as their advocate & 151 & 3.91 \\
\hline q7 I am acting as the voice of the patient when I am advocating for the patient & 151 & 3.75 \\
\hline q8 I'm acting as a representative of the patient when I act as their advocate & 153 & 4.10 \\
\hline Facilitators for the practice of advocacy & 153 & (4.26) \\
\hline q19 I can be a better patient advocate because I have more self-confidence & 152 & 3.93 \\
\hline q20 Nurses who are committed to providing good patient care are the best patient advocates & 151 & 4.42 \\
\hline q21 Greater dedication to nursing increases the ability of nurses to be patient advocates & 152 & 4.35 \\
\hline q22 A higher qualification in nursing improves the effectiveness of nurses in patient advocacy & 152 & 4.37 \\
\hline Perceptions that favor the practice of advocacy & 153 & (4.33) \\
\hline q4 Nurses who understand the benefits of patient advocacy are the best advocates for patients & 152 & 4.40 \\
\hline q26 Nurses who provide information to patients about their care are acting as their advocates & 150 & 4.23 \\
\hline q27 Patients have varying degrees of ability to defend themselves & 147 & 4.24 \\
\hline q28 Vulnerable patients need my protection in harmful situations & 149 & 4.44 \\
\hline Barriers to the practice of advocacy & 151 & (1.86) \\
\hline q41 I am not an effective advocate because I'm suffering from burnout and/or moral suffering & 150 & 2.43 \\
\hline q42 Because I do not like working as a nurse, I have less will to act as a patient advocate & 150 & 1.79 \\
\hline q43 I lack dedication to the profession of nursing to act as a patient advocate & 151 & 1.36 \\
\hline
\end{tabular}

Table 2 - Relations between the characteristics of the sample and the identified constructs - Rio Grande, RS, Brazil, 2014.

\begin{tabular}{|c|c|c|c|c|c|c|c|c|c|c|c|}
\hline \multirow{4}{*}{$\begin{array}{l}\text { Gender } \\
\text { Female } \\
\text { Male }\end{array}$} & \multirow{4}{*}{$\begin{array}{c}n \\
135 \\
16\end{array}$} & \multicolumn{2}{|c|}{$\begin{array}{l}\text { Negative implications } \\
\text { of practicing advocacy }\end{array}$} & \multicolumn{2}{|c|}{ Advocacy actions } & \multicolumn{2}{|c|}{$\begin{array}{c}\text { Facilitators for } \\
\text { practicing advocacy }\end{array}$} & \multicolumn{2}{|c|}{$\begin{array}{l}\text { Perceptions that favor } \\
\text { practicing advocacy }\end{array}$} & \multicolumn{2}{|c|}{$\begin{array}{c}\text { Barriers to } \\
\text { practicing advocacy }\end{array}$} \\
\hline & & $\mathrm{m}$ & $p$ & $\mathrm{~m}$ & $p$ & $\mathrm{~m}$ & $p$ & $M$ & $p$ & $m$ & $P$ \\
\hline & & 3.00 & .288 & 3.96 & .826 & 4.27 & .888 & 4.30 & .870 & 1.85 & .170 \\
\hline & & 2.99 & & 4.17 & & 4.20 & & 4.51 & & 1.95 & \\
\hline Age & $\mathrm{n}$ & & .615 & & .080 & & .091 & & .919 & & .268 \\
\hline$\leq 30$ years & 81 & 2.91 & & 4.14 & & 4.23 & & 4.37 & & 1.83 & \\
\hline$>30$ years & 70 & 3.06 & & 3.78 & & 4.30 & & 4.28 & & 1.83 & \\
\hline Training Time & $\mathrm{n}$ & & $.030^{*}$ & & .462 & & .598 & & .473 & & .947 \\
\hline$\leq 3$ years & 85 & 2.92 & & 4.04 & & 4.30 & & 4.39 & & 1.93 & \\
\hline$>3$ years & 68 & 3.09 & & 3.91 & & 4.22 & & 4.25 & & 1.77 & \\
\hline Experience Time & $\mathrm{n}$ & & $.045^{*}$ & & .355 & & .811 & & .329 & & .816 \\
\hline$\leq 3$ years & 75 & 2.92 & & 4.07 & & 4.29 & & 4.38 & & 1.94 & \\
\hline$>3$ years & 78 & 3.07 & & 3.90 & & 4.24 & & 4.27 & & 1.78 & \\
\hline Institution & $\mathrm{n}$ & & .648 & & .329 & & .679 & & .211 & & .746 \\
\hline $\mathrm{H} 1$ & 51 & 3.04 & & 3.88 & & 4.24 & & 4.38 & & 1.82 & \\
\hline $\mathrm{H} 2$ & 102 & 2.98 & & 4.04 & & 4.28 & & 4.30 & & 1.88 & \\
\hline Meetings & $\mathrm{n}$ & & .539 & & .835 & & .814 & & .602 & & .376 \\
\hline Yes & 106 & 3.37 & & 3.75 & & 4.21 & & 4.25 & & 2.02 & \\
\hline No & 33 & 2.87 & & 4.02 & & 4.29 & & 4.36 & & 1.81 & \\
\hline Attending & $\mathrm{n}$ & & .741 & & .121 & & .734 & & .417 & & $.038^{*}$ \\
\hline SUS & 70 & 3.11 & & 3.82 & & 4.26 & & 4.37 & & 1.79 & \\
\hline Mix & 67 & 2.98 & & 4.22 & & 4.30 & & 4.33 & & 1.98 & \\
\hline
\end{tabular}

* significance level of 5 . 


\section{DISCUSSION}

Nurses' beliefs regarding exercising patient advocacy highlighted that the construct perceptions that favor practicing advocacy had the highest average of the instrument, showing that nurses need to advocate, especially where vulnerable patients need their protection in harmful situations, agreeing that they have varying degrees of ability to defend themselves ${ }^{(19)}$.

Similar to the findings of this study, it has been found that the clinical conditions of the patients are the main antecedents of advocacy, highlighting the vulnerability of the patient among these ${ }^{(19)}$. Patients or populations are considered especially vulnerable when they cannot fully represent and protect their own rights, needs, benefits and desires; and when they are unable to make appropriate decisions or carry them out ${ }^{(19)}$.

The vulnerability of patients may be due to specific clinical situations, such as loss of consciousness, cancer, pain, mental illness, cognitive impairment, or even when they do not have enough knowledge to make decisions. The actual hospitalization can increase the vulnerability of patients because of their limited knowledge about health care in these environments and their being subjected to the care of health professionals ${ }^{(19-2)}$. However, even in vulnerable positions, it is the patients that determine the direction of their wishes and interests, so that nurses should assist them to exercise their freedom of choice, avoiding paternalistic acts ${ }^{(21)}$.

Still, when it comes to the construct perceptions that favor the practice of advocacy, nurses agree that understanding the benefits of advocacy in health and the provision of information to patients about their care can promote advocacy actions in their work environments. These beliefs may be strongly related to the practice of parrhesia, given that nurses should use direct and genuine dialogue with patients to inform them about their rights and ensure that they exercise their autonomy, since they cannot sufficiently be informed and enlightened because of restrictive practices and policies of health institutions. Similarly, understanding the benefits of patient advocacy can contribute to nurses practicing parrhesia even in facing potential risks and conflicts, since the attitude of telling the truth is a duty to help others and themselves ${ }^{(12)}$.

In relation to the construct advocacy actions, it became clear that nurses agree that they are advocating for patients in their work environments. These advocacy actions mainly include acting on behalf of patients regarding their health care, corroborating the results of other studies about the actions of nurses to advocate for patients ${ }^{(7,15,19)}$.

Studies conducted on health advocacy in different contexts have revealed that even when patients choose to have the nurse acting in their name, they are exercising their freedom of choice and autonomy ${ }^{(7,15)}$. Thus, it is necessary that nurses recognize situations where patients need a health advocate, what are the patient's interests and what actions should be taken to preserve, represent or protect them ${ }^{(19)}$.

In this sense, health advocacy actions appear to be strongly associated with the need of nurses to exercise power, which may represent the need for fighting conflicts with other professionals and institutions in order to protect patients and ensure quality of care. The challenge of defining and describing the actions of nurses in health advocacy is a complex task, given that these actions are not static or fixed, but influenced by particular characteristics of individuals, organizations, relationships, medical conditions and performance environments ${ }^{(22)}$.

In the construct facilitators to the practice of advocacy, personal values and professional skills were highlighted as the main sources of support for health advocacy actions. Thus, the characteristics of nurses can directly and positively influence the exercise of patient advocacy, such as when nurses have a higher sense of confidence that comes from their professional self-worth ${ }^{(7,16,23-24)}$.

Similarly, the knowledge and skills of nurses are considered determining factors in the practice of health advocacy and can be developed in the formation and/or during work experience through continuing education programs ${ }^{(20,24-25)}$, providing opportunities for them to be adequately trained to deal with situations that require defending patients' rights. Still, knowledge, mediated by professional qualification, can enable nurses to resist in situations they recognize as morally inadequate, favoring the exercise of power in the environments in which they operate and enhancing patient advocacy actions.

Nevertheless, the effectiveness of patient advocacy actions depend not only on the characteristics, skills and knowledge of nurses as health advocates, but on a receptive environment for this activity. It is therefore important to emphasize that the advocacy of the patient always occurs in a social setting, in that the practice of advocacy may entail negative consequences for nurses ${ }^{(7-8)}$.

Accordingly, in relation to the construct negative implications of practicing advocacy, nurses showed that they do not disagree nor agree that advocating for patients can bring them negative consequences, which is possibly related to the fact that the surveyed nurses do not realize the negative consequences of patient advocacy in their work environments. Thus, it is possible to infer that nurses successfully advocating for patients can increase their job satisfaction, confidence, credibility and visibility of nursing ${ }^{(10)}$, minimizing possible negative consequences.

With regard to the construct barriers to practicing advocacy, it was revealed that nurses disagree that barriers such as burnout and moral distress and lack of dedication to nursing may prevent them from fully realizing their role as patient advocates. Similar results were seen in studies about moral suffering, since nurses possibly may not understand the power relations in which they are immersed, experiencing the effects of moral suffering, although unable to identify it as $\operatorname{such}^{(4)}$.

Therefore, it has been identified that the moral suffering and burnout phenomena show separate signs that may not be associated to abandonment of the profession by nurses, but the remoteness of their values, beliefs and, finally, the ideals of the profession ${ }^{(3,6,26)}$, which may compromise exercising patient advocacy. 
The relationship between the variables of training time and professional experience and the construct negative implications for practicing advocacy revealed that recently graduated nurses and those with less time of professional experience showed greater disagreement regarding the negative consequences of practicing patient advocacy.

Studies on the educational preparation for the exercise of patient advocacy showed that this practice is often learned at work from observing other nurses, or after the nurses themselves have their own patient advocacy experience in their professional practice ${ }^{(7,24)}$. Thus, it can be inferred that nurses who graduated more recently and with less professional experience may not recognize the negative implications of practicing health advocacy because they have not yet had enough experiences in defending patients or because they have not yet experienced situations with negative implications.

Regarding the type of patient care, it became clear that nurses serving exclusively to SUS patients have greater disagreement regarding the barriers that can compromise the practice of advocacy when compared to the others that cater to patients of mixed units. Thus, in the perception of nurses that cater exclusively to SUS patients, barriers such as burnout and moral suffering and lack of dedication to nursing do not seem to prevent them from fully realizing their role as patient advocates.

In a study on moral suffering in two hospitals, it was possible to identify that nurses working in SUS units had a more heightened sense of moral distress than those who worked in mixed units ${ }^{(4)}$. However, the intensified perception of moral suffering can be linked to fully exercising their nursing role in patient advocacy, especially when the service in SUS units is intended for patients whose social and economic conditions may be less favorable, therefore, more socially vulnerable, which may hinder or decrease their access to better information, and also their chances to defend themselves compared to patients of private units ${ }^{(2,4)}$.

Thus, health disparities motivated by factors such as poverty and access to health services may constitute important reasons to advocate. From this perspective, exercising patient advocacy in hospitals may also be associated with the creation of conditions of autonomy, equality and justice in social relations, as well as equal access to opportunities for all people (27-29). $^{2}$.

\section{CONCLUSION}

The study revealed that nurses in the surveyed sample believe they are advocating for patients in their workplaces, agreeing that they should especially advocate when vulnerable patients need their protection in harmful situations. Personal values and professional skills have been identified as major sources of support for the practice of advocacy; barriers such as burnout, moral suffering and lack of dedication to nursing were identified as obstacles to its exercise.

It was also possible to verify that nurses do not seem to recognize the negative implications of practicing advocacy, since they do not agree nor disagree that advocating for patients can bring them negative consequences. Thus, it is believed that when nurses advocate for patients, they base their actions on values recognized as ethical in health, feeling more protected with their decisions and in feeling relieved, despite possible implications of exercising patient advocacy.

There were no significant differences regarding the beliefs and actions of nurses according to the surveyed hospitals, even when dealing with the different organizations of public and philanthropic. This finding proves relevant, since hospitals that provide greater openness to dialogue, freedom to act and job security contribute more effectively to nurses being able to advocate for the interests of patients. So, the question is: How do the characteristics of public and private institutions help or not help in nurses exercising patient advocacy?

To answer such a question, further investigations on patient advocacy practice are necessary due to the relevance of further peculiarities of the relationship between job security of nurses and their beliefs and actions in relation to exercising patient advocacy.

As a limitation of this study, we can cite the fact that it was conducted with a specific sample of nurses in two hospitals in southern Brazil, which does not allow for generalizing the results. Although the sample was representative, it possibly does not resemble the multiple existing health contexts in Brazil.

\section{RESUMO}

Objetivo: Analisar as crenças e ações de enfermeiros no exercício da advocacia do paciente no contexto hospitalar. Método: Estudo quantitativo, exploratório-descritivo, com delineamento transversal, realizado com 153 enfermeiros de duas instituições hospitalares do sul do Brasil, uma pública e uma filantrópica, mediante aplicação do Protective Nursing Advocacy Scale - versão brasileira. Os dados foram analisados através de estatística descritiva e análises de variância. Resultados: Os enfermeiros acreditam que estão advogando pelos pacientes em seus ambientes de trabalho, concordando que devem advogar, especialmente quando pacientes vulneráveis precisam da sua proteção. Os valores pessoais e a qualificação profissional foram identificados como principais fontes de apoio ao exercício da advocacia. Conclusão: Os enfermeiros nem discordam e nem concordam que advogar pelos pacientes em seus ambientes de trabalho possa lhes trazer consequências negativas. Faz-se necessário reconhecer como as características das instituições públicas e privadas vêm favorecendo, ou não, o exercício da advocacia do paciente pelos enfermeiros.

\section{DESCRITORES}

Defesa do Paciente; Direitos do Paciente; Relações Enfermeiro-Paciente; Ética em Enfermagem; Papel do Profissional de Enfermagem. 
RESUMEN

Objetivo: Analizar las creencias y acciones de enfermeros en el ejercicio de la defensa del paciente en el marco hospitalario. Método: Estudio cuantitativo, exploratorio-descriptivo, con corte transversal, realizado con 153 enfermeros de dos instituciones hospitalarias del sur de Brasil, una pública y una filantrópica, mediante aplicación del Protective Nursing Advocacy Scale - versión brasileña. Los datos fueron analizados por medio de estadística descriptiva y análisis de varianza. Resultados: Los enfermeros creen que están luchando por los pacientes en sus ambientes laborales, concordando que deben defenderlos, especialmente cuando los pacientes vulnerables necesitan su protección. Los valores personales y la calificación profesional fueron identificados como las principales fuentes de apoyo al ejercicio de la defensa. Conclusión: Los enfermeros no están de acuerdo ni tampoco están de acuerdo que defender a sus pacientes en sus ambientes laborales pueda traerles consecuencias negativas. Se hace necesario reconocer cómo las características de las instituciones públicas y privadas están favoreciendo, o no, el ejercicio de la defensa del paciente por los enfermeros.

\section{DESCRIPTORES}

Defesa del Paciente; Derechos del Paciente; Relaciones Enfermero-Paciente; Ética en Enfermería; Rol de la Enfermera.

\section{REFERENCES}

1. Jameton A. Nursing practice: the ethical issues. Englewood Cliffs: Prentice-Hall; 1984.

2. Barlem ELD, Lunardi VL, Lunardi GL, Dalmolin GL, Tomaschewski JG. The experience of moral distress in nursing: the nurses' perception. Rev Esc Enferm USP [Internet]. 2012 [cited 2014 July 25];46(3):681-8. Available from: http://www.scielo.br/pdf/reeusp/v46n3/en_21.pdf

3. Barlem ELD, Lunardi VL, Lunardi GL, Tomaschewski-Barlem JG, Silveira RS. Moral distress in everyday nursing: hidden traces of power and resistance. Rev Latino Am Enfermagem. 2013;21(1):293-9.

4. Barlem ELD, Lunardi VL, Lunardi GL, Tomaschewski-Barlem JG, Silveira RS, Dalmolin GL. Moral distress in nursing personnel. Rev Latino Am Enfermagem. 2013 21(n.spe):79-87.

5. Barlem ELD, Lunardi VL, Tomaschewski JG, Lunardi GL, Lunardi Filho WD, Schwonke CRGB. Moral distress: challenges for an autonomous nursing professional practice. Rev Esc Enferm USP. 2013;47(2):506-10.

6. Dalmolin GL, Lunardi VL, Lunardi GL, Barlem ELD, Silveira RS. Moral distress and Burnout syndrome: are there relationships between these phenomena in nursing workers? Rev Latino Am Enfermagem. 2014;22(1):35-42.

7. Hanks RG. The medical-surgical nurse perspective of advocate role. Nurs Forum. 2010;45(2):97-107.

8. Hanks RG. Development and testing of an instrument to measure protective nursing advocacy. Nurs Ethics. 2010;17(2):255-67.

9. Reed FM, Fitzgerald L, Bish MR. District nurse advocacy for choice to live and die at home in rural Australia: a scoping study. Nurs Ethics. 2014 Jun 29. [Epub ahead of print]

10. Mahlin M. Individual patient advocacy, collective responsibility and activism within professional nursing associations. Nurs Ethics. 2010;17(2):247-54.

11. Cole C, Wellard S, Mummery J. Problematising autonomy and advocacy in nursing. Nurs Ethics. 2014;21(5):576-82.

12. Foucault M. Fearless speech. Los Angeles: SEMIOTEXT(E); 2001.

13. Drought T. Parrhesia as a conceptual metaphor for nursing advocacy. Nurs Ethics. 2007;14(2):127-8.

14. Foucault M. Microfísica do poder. $26^{\mathrm{a}}$ ed. Rio de Janeiro: Graal; 2008.

15. Vaartio H, Leino-Kilpi H, Suominen T, Puukka P. Nursing advocacy in procedural pain care. Nurs Ethics. 2009;16(3): 340-62.

16. Josse-Eklund A, Jossebo M, Sandin-Bojo AK, Wilde-Larsson B, Petzall K. Swedish nurses' perceptions of influencers on patient advocacy. Nurs Ethics. 2014;21(6):673-83.

17. Hill MM, Hill A. Investigação por questionário. Lisboa: Sílabo; 2012.

18. Tomaschewski-Barlem JG. O exercício da advocacia do paciente pelos enfermeiros: uma perspectiva foucaultiana [tese doutorado]. Rio Grande: Programa de Pós-Graduação em Enfermagem, Universidade Federal do Rio Grande; 2014.

19. Bu X, Jezewski MA. Developing a mid-range theory of patient advocacy through concept analysis. J Adv Nurs. 2007;57(1):101-10.

20. O'Connor T, Kelly B. Bridging the Gap: a study of general nurses' perceptions of patient advocacy in Ireland. Nurs Ethics. 2005;12(5):453-67.

21. Zomorodi M1, Foley BJ. The nature of advocacy vs. paternalism in nursing: clarifying the 'thin line'. J Adv Nurs. 2009;65(8):1746-52.

22. Simmonds AH. Autonomy and advocacy in perinatal nursing practice. Nurs Ethics. 2008;15(3):360-70.

23. Negarandeh R, Oskouie F, Ahmadi F, Nikravesh M. The meaning of patient advocacy for Iranian nurses. Nurs Ethics. 2008;15(4):457-67.

24. Thacker KS. Nurses' advocacy behaviors in end-of-life nursing care. Nurs Ethics. 2008;15(2):174-85.

25. Gazarian PK, Fernberg LM, Sheehan KD. Effectiveness of narrative pedagogy in developing student nurses advocacy role. Nurs Ethics. 2014 Dec 10. [Epub ahead of print]

26. Lunardi VL, Barlem EL, Bulhosa MS, Santos SS, Lunardi Filho WD, Silveira RS, et al. Moral distress and the ethical dimension in nursing work. Rev Bras Enferm. 2009;62(4):599-603.

27. Pavlish C, Ho A, Rounkle A. Health and human rights advocacy: perspectives from a Rwandan refugee camp. Nurs Ethics. 2012;19(4):538-49.

28. Ware LJ, Bruckenthal P, Davis GC, O'Conner-Von SK. Factors that influence patient advocacy by pain management nurses: results of the American society for pain management nursing survey. Pain Manag Nurs. 2011;12(1):25-32.

29. Toda Y, Sakamoto M, Tagaya A, Takahashi M, Davis AJ. Patient advocacy: Japanese psychiatric nurses recognizing necessity for intervention [abstract]. Nurs Ethics. 2014 Sept 22. [Epub ahead of print] 